\title{
HOW TO BE IMPOLITE IN ANCIENT GREEK: SILENCERS AND DISMISSALS IN GREEK COMEDY*
}

\author{
Paola DARDANo** \\ Università per Stranieri di Siena
}

\begin{abstract}
This paper examines impoliteness in ancient Greek, taking into account the linguistic structure of silencers and dismissals, their communicative functions and their gender distribution in three comedies by Aristophanes. Silencers and dismissals serve a number of different communicative goals: reinforcing disagreement, creating comic effect, and advancing the plot. We will analyse the possibilities that speakers have at their disposal to express them, and the interference that occurs with other speech acts that are conceptualised in a similar way.
\end{abstract}

KEYWORDS: Historical (im)politeness, silencer, dismissal, Greek comedy, Aristophanes.

* I am indebted to Luz Conti for very helpful comments and criticism that helped me improve the formulation of what follows. I also express my warmest thanks to the two anonymous reviewers for valuable suggestions.

\footnotetext{
** Correspondence to: Paola Dardano, Università per Stranieri di Siena, Piazza Carlo Rosselli 27/28 (53100 Siena) - dardano@unistrasi.it - https:// orcid.org/0000-0002-4221-8716.

How to cite: Dardano, Paola (2022), "How to be impolite in ancient Greek: silencers and dismissals in Greek comedy», Veleia, 39, 65-83. (https://doi. org/10.1387/veleia.22300).

Received: 2020 december 1; Final version: 2021 july 2.
}

ISSN 0213-2095 - elSSN 2444-3565 / (C) 2022 UPV/EHU

(i) $(-)$ This work is licensed under a

cc) 
1. Linguistic impoliteness, defined as an intentional face attack by a speaker on an addressee, is a well-documented phenomenon in Greek comedy. Indeed, impoliteness between characters is a recurrent feature in entertaining audiences, and Aristophanes makes extensive use of it; in addition to being an easy way to make an audience laugh, it is also very effective as a means of advancing the plot. Moreover, it allows the playwright to demonstrate his wit and verbal creativity, for example in an escalation of insults between characters. Most of the impoliteness strategies evident in Aristophanes' comedies are still found in modern societies, which suggests that concepts of face attack through impoliteness are universal ${ }^{1}$.

Greek and Latin has recently become the subject of various studies from this perspective, but there is still much work to be done, as many spheres that merit detailed research remain unexplored. The present paper thus aims to help fill this gap in pragmatic studies by testing a linguistic theory regarding impoliteness on an ancient Greek genre. The question addressed here is whether material that has already been thoroughly studied can benefit from the application of politeness theories. This examination will take into account both the expressive potential of silencers and dismissals and how these may overlap with other communicative intentions, bearing in mind that the language of the comedy (at least that of Aristophanes) is clearly often meant to be impolite (and even vulgar) for comic effect.

As opposed to other speech acts, such as insults, silencers and dismissals have not received much attention from scholars and few publications have been dedicated exclusively to this topic. This is thus the first occasion that a comprehensive analysis has been presented of the typology of silencers and dismissals in Aristophanes and of the conditions governing their use. The article is organised as follows: Section 2 provides an overview of the theoretical framework and the corpus, while Section 3 presents and analyses the data, by also offering an interpretation of usage. Finally, Section 4 discusses the results from a broad pragmatic perspective.

2.1. Before moving on to the analysis of the data, certain theoretical and terminological issues must be discussed. It is well known that the field of (im)politeness was established within the framework of linguistic pragmatics. Brown \& Levinson 1987 distinguish two major politeness strategies, that is, "positive politeness strategies", and "negative politeness strategies", which correspond to two types of "face", that is, "positive face" and "negative face". Positive politeness is redress directed at the addressee's positive face, his constant desire being that his needs should be seen as desirable. Negative politeness is redressive action directed at the addressee's negative face: the desire of the addresse is to have his freedom of action unhindered and his attention unimpeded.

According to this theory, the factors that influence the choice of politeness strategies are the amount of intimacy or distance between speaker and addressee, the power differential between them, and the scale of the issue that gives rise to the need for politeness (a request, a problem requiring an apology, etc.). Negative politeness is used when there is a greater distance between speaker and addressee, when the addressee has a significant amount of power over the speaker, and/or when the issue at hand is of considerable importance. Positive politeness is used when there is a greater intimacy between the parties, when the speaker is equal or superior to the addressee in power or status, or when the issue at hand is minor (Brown \& Levinson 1987: 71-84).

\footnotetext{
1 The last fifty years or so of politeness research (if we take Brown and Levinson's 1978 seminal work as a convenient starting point) have brought about considerable advances in the methodology and understanding of the
}

issues at hand. Many of these advances have also been applied to historical contexts, although much remains to be done. On historical (im)politeness, see Ehlich 1992; Culpeper \& Kádár 2010; Bax \& Kádár 2012. 
Although Brown and Levinson's theory has attracted much criticism², it remains popular as a paradigm for analysing linguistic politeness as it offers something that none of its detractors has been able to replace: a simple template that can be used to examine the politeness system of a language. However, their theory focuses on harmonious interaction, and thus, quite understandably, ignores impoliteness. In particular, they tend to give the impression that impoliteness is either some kind of pragmatic failure, a consequence of not doing something, or merely anomalous behaviour that is not worth considering. Impoliteness, however, has an intimate, albeit not a straightforward, relation to politeness in that we should not consider impoliteness as the natural antithesis to politeness, i.e., linguistic impoliteness is not the simple mirror image of linguistic politeness ${ }^{3}$. This means that we need to develop and refine our analytical tools to investigate issues of politeness and impoliteness (see Culpeper \& Kádár 2010; Culpeper, Haugh \& Kádár 2017). It is too simplistic to believe that while politeness is concerned with mitigating face-damage, impoliteness is concerned with aggravating it. Impoliteness consists of communicative strategies designed to attack face, and it thereby causes social conflict and disharmony. In their definitions of impoliteness, some scholars place the emphasis on intentionality: "Impoliteness constitutes the communication of intentionally gratuitous and conflictive verbal face-threatening acts which are purposefully delivered: (i) unmitigated [...], and /or (ii) with deliberate aggression [...] (Bousfield 2008, 72; our emphasis); "Impoliteness comes about when: (1) the speaker communicates face-attack intentionally, or (2) the hearer perceives behaviour as intentionally face-attacking, or a combination of (1) and (2)" (Culpeper 2005,38 ). It is useful to start from an overview of how unfavourable social behaviour is realised verbally. Culpeper 2010a, 3242-3243 offers a corpus-based selection of conventionalized impoliteness formulae divided into several categories: insults (e.g. you fucking moron), pointed criticisms (e.g. that was absolutely rubbish), challenging or unpalatable questions and/or presuppositions (e.g. why do you make my life impossible?), condescension (e.g. that's childish), message enforcers (e.g. you got it?), dismissals (e.g. get lost), silencers (e.g. shut your fucking mouth), threats (e.g. X before I hit you), and negative expressions (e.g. damn you). This is of course a list of impoliteness formulae in British English. Whether the same types of impoliteness formulae hold true in other languages and cultures is an unanswered empirical question, but they offer a useful categorization.

Silencers and dismissals can be considered as intentional face-attacks involving positive impoliteness, if we define positive impoliteness as the use of strategies designed to damage the addressee's positive face wants, e.g. to ignore the other, exclude them from an activity, be disinterested, unconcerned or unsympathetic, use inappropriate identity markers, use obscure or secretive language, seek disagreement or use taboo words ${ }^{4}$.

\footnotetext{
2 Brown \& Levinson 1987 argue that their theory has universal validity, but this presupposes that all cultures in the world have identical notions of "self" or "face", something that does not seem to be true. The relationship between "face" and "politeness" has also been criticised: the view that face motivates politeness is a very strong assumption, which does not seem to hold up against crosscultural evidence. The impact of contextual variables (i.e. age, sex, social class) may also vary across cultures. Brown and Levinson's theory has also been criticised for being Anglo-centric by failing to take into account norms and practices of politeness in other cultures. On (im)politeness and discursive practices, see Watts 2003.
}

\footnotetext{
3 Eelen 2001, 98-100 argues that politeness theories are generally not well equipped, conceptually or descriptively, to account for impoliteness.

${ }^{4}$ Conversely, negative impoliteness implies the use of strategies designed to damage the addressee's negative face wants, e.g. to frighten, condescend, scorn or ridicule, to be contemptuous, not to treat the other seriously, belittle the other or invade the other's space (literally or metaphorically). Additionally, the other might also be associated explicitly with a negative aspect (personalising, using the pronouns 'I' and 'You') or putting their indebtedness on record.
} 
However, the situation is more complicated that it might seem. If impoliteness involves behaviour that intentionally attacks or is perceived to attack positive identity values that people claim for themselves, or norms regarding how people think people should be treated, investigating impoliteness must also involve the study of particular communicative behaviour in social interaction. It has been noted that apparently impolite acts or forms can be a means of showing friendliness or solidarity, and that, conversely, ostensibly polite acts or forms can function as coercion or aggression (Leech 1983). Moreover, a conventionalised impoliteness formula could be used in a context where it is interpreted as banter, and thus the ultimate construal of the communication is that it is far from being impolite. The more intimate a relationship, the less necessary and important politeness is, and thus lack of politeness can be associated, amongst other things, with intimacy. There is little doubt that it is important to recontextualise impoliteness and to distinguish between genuine vs. mock impoliteness. Mock impoliteness relies on some degree of mismatch between conventionalised impoliteness formulae and the context, along with additional signals (e.g. laughter) that the impoliteness is not genuine.

Mixed messages, be it teasing, irony, (ritualised) banter or some other form, can easily create a certain degree of confusion not only for their targets, but also for researchers. The fact that mixed messages involve recourse to both politeness and impoliteness means that participants inevitably must have some degree of awareness of the way in which a message understood literally as polite, for instance, may at the same time convey impoliteness. This means that all pragmatic analyses must be contextualised and that there can be no sweeping generalizations. The context of interaction plays a crucial role. Eelen 2001 has argued that (im)politeness is not an inherent quality of an utterance, but a quality attributed to an utterance within a specific context of use. It is clear that no linguistic expression can be considered as inherently (im)polite, but must depend on the evaluations that the interlocutors makes.

2.2. Until now, however, these methods and techniques have largely been applied to spoken language, which can be observed, described and analysed in great detail. Its application to written documents remains disputed and has attracted relatively little attention. Nevertheless, the fact that (im)politeness strategies have been mostly based on English data does not preclude their applicability to other languages such as ancient Greek ${ }^{6}$. When we are dealing with ancient languages, our perspective can only be that of an external observer. Even so, this does not preclude recourse to these theories in order to provide us with explanations for specific linguistic behaviour in classical languages ${ }^{7}$.

Despite the progress made in recent years in this field, the study of (im)politeness in ancient languages poses certain theoretical and methodological problems that are difficult to resolve. In addition to any shortfalls in linguistic competence, it should be noted that the available corpora present various limitations; e.g. there can be no analysis of prosodic features or gestures, which play an important part in the creation of (im)politeness and clarify the communicative intent of an utterance. What is more, given that the expression of (im)politeness is greater in interactions, we need to make use of texts that document conversations, whether in praesentia (theatre, dialogues

\footnotetext{
5 See Kienpointner 1997, Mills 2003, Watts 2003, Culpeper 2010a, Culpeper 2010b among others.

6 The notion of (im)politeness has been applied to ancient Greek by some scholars including Lloyd 2006; Denizot 2012; Poccetti 2014.
} 
in novels or epic poems, speeches, etc.) or in absentia (letters, inscriptions, etc.). This means that our already limited sources are reduced even further. Moreover, given that textual transmission is somewhat down to luck, any quantitative analysis of certain expressions should also be made with due caution.

Bearing these obstacles in mind, one possible way to approach (im)politeness phenomena in ancient languages is to choose a corpus containing as few variables in speaker type or genre as possible in order to help isolate the effects of other, more important variables. For this kind of analysis, comedy is an ideal corpus. Firstly, it includes a large amount of spoken data, such as conversation and dialogue, which provide excellent material for linguistic research on (im)politeness. Secondly, due to the fact that drama is a record of spoken dialogue, we can also elicit information from the hearer's reactions to the speaker's linguistic behaviour. Thirdly, from the colloquial features of the language we can deduce that comedy in some way reflects the spoken language of the time, even though comic diction should never be considered a simple transcription of spoken language ${ }^{8}$.

The uses of silencers and dismissals available in three comedies by Aristophanes, namely Lysistrata, Women to the Festival (Thesmophoriazusae) and Women to the Assembly (Ecclesiazusae) [henceforth Lys., Thesm. and Eccl.] will be analysed'. The choice of these texts has a considerable advantage in that they represent a relatively homogeneous body of material from a well-defined period of time ${ }^{10}$. Dismissals and silencers are common in this corpus, thus providing an ideal source for determining how and when they were used. An interesting aspect of this investigation will be whether an extra-linguistic factor, i.e. the gender of the speaker, plays a significant role ${ }^{11}$. Indeed, all three comedies present both male and female characters on stage, thus providing an opportunity to compare linguistic features according to the gender of the speaker ${ }^{12}$. Particularly interesting in terms of linguistic characterization are the disguised characters who adopt the speech patterns of the people they mimic. Thesm. portrays two main characters who are disguised as women at some point in the play: the plot of the comedy is about the unnamed kinsman of Euripides who is disguised as a woman to go the Festival and spy on the other women. Conversely, Eccl. portrays women disguised as men, who attend the assembly. Special attention will therefore be given to the gender of the speaker, not only distinguishing between male and female characters, but also char-

\footnotetext{
8 This can be fully appreciated if we bear in mind that comedies were written in verse and that many parts were sung. On conversational language in Aristophanes, see López Eire 1996; Dickey 1995. For a comprehensive study of figurative language in Aristophanes, see Taillardat 1965.

9 The data were collected not via electronic searches but by reading through the plays themselves. This method of data collection allows features to be observed that cannot easily be identified via electronic searches, such as imperatives, hedges, and even indirect requests (e.g. those not actually expressed, but inferable from the context). The data have been selected in the three aforementioned Aristophanic comedies, basing on Wilson (2007) critical edition. Unless otherwise noted, translations are taken from Austin \& Olson 2004, Sommerstein 1990, Sommerstein 1998.
}

10 The Aristophanes' so-called 'female' comedies, i.e. Lys. (411 a. C.), Thesm. (411 a.C.) and Eccl. (391 a.C.), belong to a stage of creative maturity, but do not respond a preconceived plan on the part of the playwright.

11 The complex interrelationship between gender and (im)politeness has been explored from a number of different research angles over the past 40 years, particularly within the linguistic disciplines of pragmatics and sociolinguistics. It has been suggested that women develop a cooperative speech style and observe social rules of politeness more than men; see Holmes 1995, Mills 2003. Nevertheless, we should be careful not to map modern European categories of gendered language onto historical societies unless the evidence gives us good reason to do so.

12 The three plays also contain satire on adultery and the relations between the sexes. On the language of male characters in Aristophanes, see McDonald 2016. 
acters in disguise ${ }^{13}$. Evaluating the variables (the gender of the speaker, the social distance between speaker and addressee, the power difference between them) allows us to uncover the impoliteness strategies employed, enabling a discussion of the relation between these contextual factors and the type of impoliteness strategy used in the individual cases.

3.1. The classification of impoliteness formulae is a complex matter and not one that is exclusively confined to register issues. While insults are often classified by their lexical meaning, and such a method can produce interesting results, it is not one that is particularly useful to the present inquiry, which is primarily concerned with social meaning. The social meaning of silencers and dismissals, like that of any other form of impolite expressions, is not necessarily determined by their lexical meaning. This is evident from the fact that some words with offensive lexical meanings are not insults when part of banter - and might even be terms of affection — and from the fact that the same expression can have different social meanings in different cultures that share the same language.

3.2. Silencers very often have the function of advancing the plot or preparing the audience for what is about to happen on stage. More than once, Euripides invites the In-law to keep quiet: when they approach Agathon's house (1), when Agathon's slave speaks (2), and when Agathon enters the scene (3) and begins to sing (4):

(1) Thesm. 26-30

Ev.

Kh.

Ev.

Kh.

Ev.

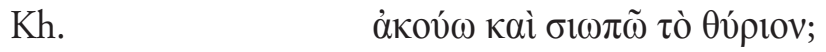

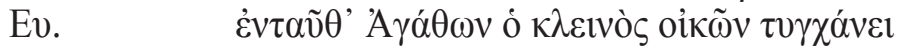

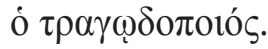

Euripides Do you see that little door?

Mnesilochus Yes, certainly.

Euripides Silence!

Mnesilochus Silence about what? About the door?

Euripides Pay attention!

Mnesilochus Pay attention and be silent about the door? Very well.

Euripides That is where Agathon, the celebrated tragic poet, dwells.

In (1) Euripides means simply 'Be silent!' but the In-law, who is eager to cooperate despite being a bit behind the curve (as he frequently is in this scene), interprets it as 'Be silent [about this]!', and therefore responds 'I won't say anything about the door!'. The In-law's refusal to keep quiet as requested makes it difficult for Euripides to hear what Agathon's slave is saying:

\footnotetext{
13 Gender is a sociolinguistic variable, which has received some attention, particularly with regard to the Classical period. Studies by Sommerstein 1995 and Willi 2003, 157-197, for example, present a catalogue of genderspecific features in Greek comedy. On women's language
}

in Greek and Latin, see Fögen 2004, Fögen 2010. However, it should be stressed that the vast majority of sources were not written by women themselves, but by elite Greek and Roman males. It is therefore questionable whether the available data are an accurate reflection of women's speech. 
(2) Thesm. 45

Ev.

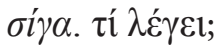

Euripides Be still! I want to hear what he is saying.

Later, Agathon enters the scene:

(3) Thesm. 95

Ev.

$\sigma i \gamma \alpha$.

Kh.

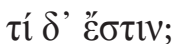

Ev.

Euripides

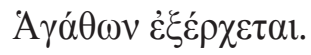

Mnesilochus What's the matter?

Euripides Here comes Agathon.

(4) Thesm.99

Ev.

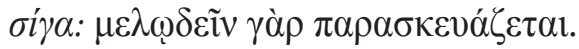

Euripides Be still! He is getting ready to sing.

Sometimes the request to be silent signals the beginning of a public speech. In (5) the Woman Herald invites the audience to be silent and pray to the gods that the assembly is being convened in the fairest and best fashion:

(5) Thesm. 295-305

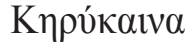

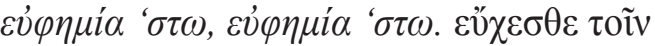

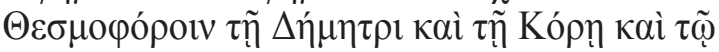

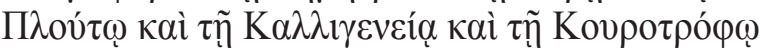

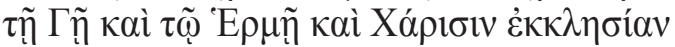

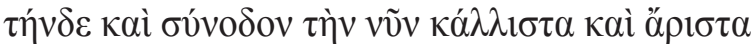

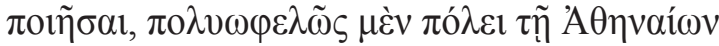

$\tau v \chi \eta \rho \tilde{\omega} \varsigma \delta^{\prime} \dot{\eta} \mu \tilde{i} v \alpha$ $\alpha \alpha \tilde{\iota} \varsigma$.

Woman Herald

Silence! Silence! Pray to the Thesmophorae, Demeter and Cora; pray to Plutus, Calligenia, $\mathrm{Cu}-$ rotrophus, the Earth, Hermes and the Graces, that all may happen for the best at this gathering, both for the greatest advantage of Athens and for our own personal happiness!

The instance in (6), when Praxagora acts the part of the Assembly Herald at the very beginning of the meeting, might also be interpreted in a similar way:

(6) Eccl. 129-130

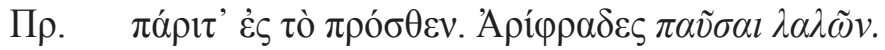

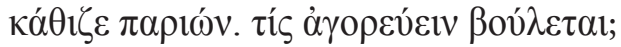

Praxagora Step forward, please! Silence, Ariphrades! Go and take your seat. Now, who wishes to speak?

In (7) the exhortation to the audience 'Be still! ... Pay attention!' clearly approximates the sort of things heralds said routinely at the beginning of a meeting of the Assembly:

(7) Thesm. 381-382

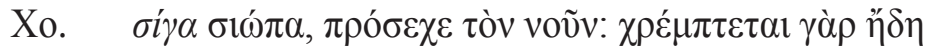




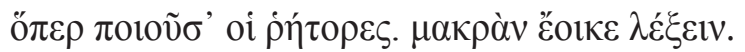

Leader of the Chorus Be still! Let all be quiet! Pay attention! For here she is spitting as orators generally do before they begin; no doubt she has much to say.

In (8) the silencer has the function of solemnly introducing an oracle's verdict. Lysistrata rallies her "troops" like a general. She reminds the wives of what she has told them earlier and prepares them for the oracle that will follow. She produces a written oracle that was composed for this emergency, which is parodic with flagrant double entendres. Animals frequently represent human beings in oracles, and $\chi \varepsilon \lambda \iota \delta \omega$ v 'swallow' is a slang term for the female genitals:

(8) Lys. 767-773

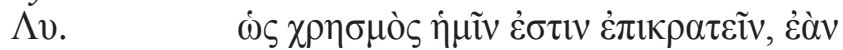

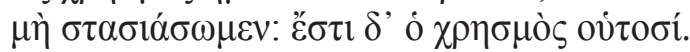

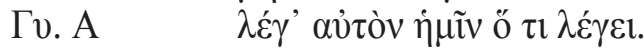

$\Lambda v$.

$\sigma l \gamma \tilde{\alpha} \tau \varepsilon \delta \dot{\eta}$.

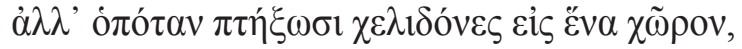

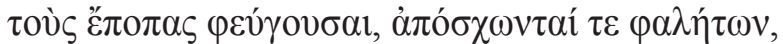

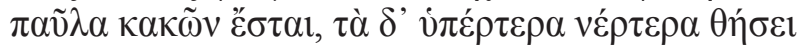

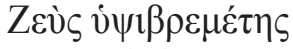

Lysistrata An oracle has promised Victory If we don't wrangle. Would you hear the words?

Woman Yes, yes, what is it?

Lysistrata

\section{Silence then,}

You chatterboxes. Here- When as the swallows flocking in one place from the hoopoes deny themselves love's gambols any more,

all woes shall then have ending and great Zeus the Thunderer

shall put above what was below before.

Silencers are often accompanied by other impolite expressions: a command in $(9,10,11)$, a threat in (12) and even an insult in (13):

(9) Lys. 586-590

Пр.

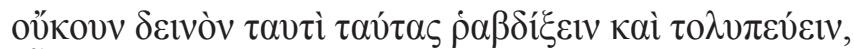

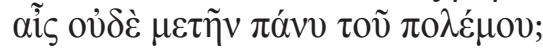

$\Lambda v$.

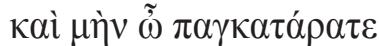

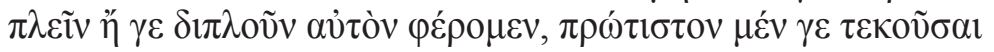

Пр.

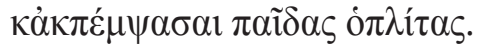

Magistrate How terrible is it to stand here and watch them carding and winding at will with our fate, Witless in war as they are.

Lysistrata What of us then, who ever in vain for our children must weep borne but to perish afar and in vain?

Magistrate Not that, O let that one memory sleep!

(10) Eccl. 1088

Гра. B

$\Gamma \rho \alpha . \Gamma$

$\sigma l \gamma \tilde{\eta} \beta \alpha ́ \delta 1 \zeta \varepsilon$ $\delta \varepsilon \tilde{v} \rho \circ$.

$\mu \grave{\alpha} \Delta \mathfrak{i}^{\prime} \alpha^{\prime} \lambda \lambda{ }^{\prime} \dot{\omega} \varsigma \dot{\varepsilon} \mu \varepsilon^{2}$. 
Second Old Woman Then come along, do, and hold your tongue.

Third Old Woman No, by Zeus, come with me.

A little earlier, the Second Old Woman had said:

(11) Eccl. 1057-1058

$\mathrm{N} \varepsilon \alpha$.

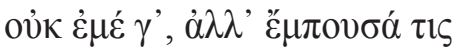

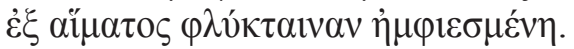

Гра. B

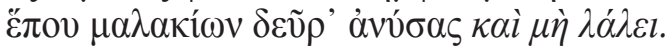

Young Man

No, it's not the law, but an Empusa with a body covered with blemishes and blotches

Second Old Woman Follow me, my handsome little friend, come along quickly without any more ado.

In (11) a silencer is accompanied by the affectionate address $\mu \alpha \lambda \alpha \kappa i \omega v$. It would obviously be wrong to suppose that this affectionate diminutive expresses genuine affection; the context indicates the opposite and its use is tactical, that is, to create in the addressee an attitude favourable to the speaker. This is a typical mixed message, a message containing features that suggest a polite interpretation alongside features that suggest an impolite one. It is a pragmatic strategy that simultaneously acts on the positive and the negative face of the addressee: indeed, the diminutive $\mu \alpha \lambda \alpha \kappa i \omega v$ is a term of endearment that pleases the positive face of the hearer, while, at the same

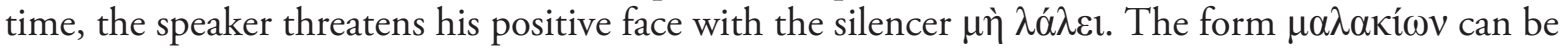
taken as a term of endearment, but elsewhere $\mu \alpha \lambda \alpha \kappa o$ s 'soft' is pejorative when applied to males, and so the old woman is probably taunting the Young Man for being so unmanly that he is frightened of an ugly face. Moreover, the diminutive could be interpreted as increasing the irony of the situation, often at the expense of a male character in order to enhance the comic effect. In addition, the verb $\lambda \alpha \lambda \varepsilon \dot{\varepsilon} \omega$ 'to chatter', but also 'to talk (too much)' or 'to talk (out of turn)' is often used by characters in the plays to refer to women's speech, and is often associated with negative attitudes to how women speak, or to the fact that they speak at all (see Willi 2003,169). In comedy and related genres, the image of the talkative woman is exploited as a topos, employed to evoke laughter and ridicule. Here the verb $\lambda \alpha \lambda \dot{\varepsilon} \omega$ is used with reference to a man, and this of course increases the comic effect.

In (12) the two semichoruses of the old women and the old men threaten each other after exchanging insults that become increasingly more violent:

(12) Lys. 364-366

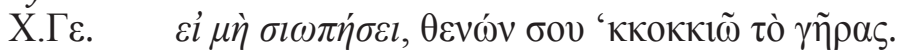

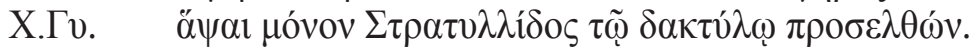

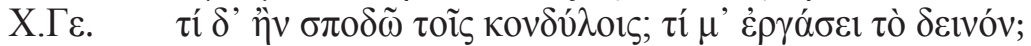

Men Be quiet, or I'll bash you out of any years to come.

Women Now you just touch Stratyllis with the top-joint of your thumb.

Men What vengeance can you take if with my fists your face I beat?

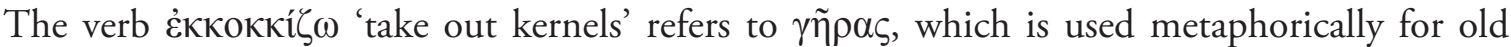
skin, lit. 'knock the seeds of your old skin', i.e. 'beat you to a pulp'. It is also important to note the reaction to the silencer. One could simply ignore impoliteness and not respond at all, but if one responds, one has a choice as to how to respond. The choice seems to be between accepting the impoliteness or countering it. Acceptance involves agreeing with an insult, complying with a rude 
demand and so on, while countering involves actively challenging the impoliteness. Finally, how one counters is a further issue, and there seems to be a range of options varying from being offensive to being defensive (as in the previous example).

In (13) the Scythian archer orders Euripides' In-law disguised as a woman to keep quiet and adds

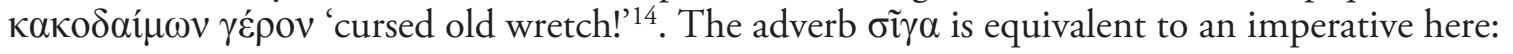

(13) Thesm. 1006-1007

Kh.

$\dot{\alpha} \tau \tau \alpha \tau \alpha \tilde{i} \mathbf{\alpha} \alpha \tau \alpha \tau \alpha \tilde{:}:$

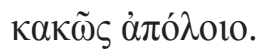

To.

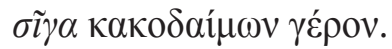

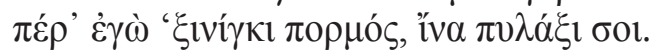

Mnesilochus Oh! Oh! Ow! Ow! May the plague take you!

Scythian Archer Silence! You cursed old wretch! I am going to get a mat to lie upon, so as to watch you close at hand at my ease.

Sometimes we have a more elaborate formulation of the silencer that involves animal noises. Euripides tells the In-law to 'Stop crying $\beta \alpha$ î̉ $\beta \alpha$ oû́!', i.e. 'Stop yapping at him, harassing him!', as

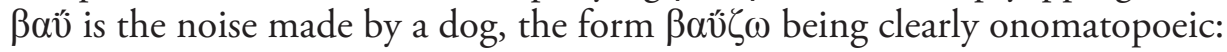

(14) Thesm. 172-175

Kh.

Ev. $\pi \tilde{\omega} \varsigma \pi \rho \grave{\varsigma} \varsigma \tau \tilde{\omega} v \theta \varepsilon \tilde{\omega} v$

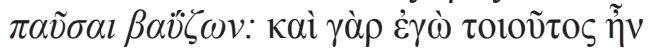

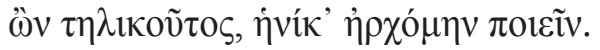

Mnesilochus How, in the gods' name?

Euripides Come, leave off badgering him; I was just the same at his age, when I began to write.

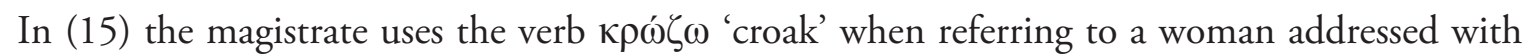
the less than polite title $\gamma \rho \alpha \tilde{v}$ 'old woman' to enhance the comic situation:

(15) Lys. 502-506

Пр.

$\Lambda v$.

Пр.

$\Lambda v$.

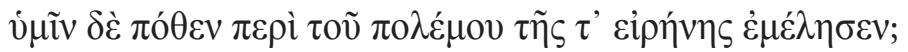

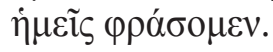

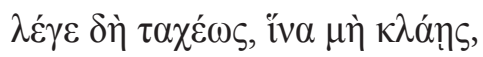

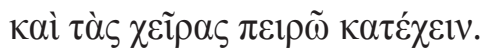

Пр.

Гv. A.

Пр.

$\Lambda v$.

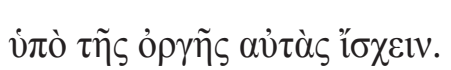

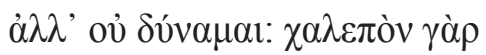

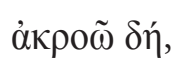

Magistrate Why do you women come prying and meddling in matters of state touching war-time and peace?

Lysistrata That I will tell you.

Magistrate $\quad \mathrm{O}$ tell me or quickly I'll-

\footnotetext{
14 On insults as forms of address, see Dickey 1996,

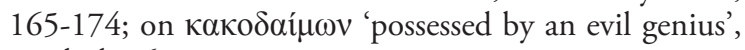
see ibid. 168.
} 
$\begin{array}{ll}\text { Lysistrata } & \text { Hearken awhile and from threatening cease. } \\ \text { Magistrate } & \text { I cannot, I cannot; it's growing too insolent. } \\ \text { Women } & \text { Come on; you've far more than we have to dread. } \\ \text { Magistrate } & \text { Stop from your croaking, old carrion-crow there... Continue } \\ \text { Lysistrata } & \text { Be calm then and I'll go ahead. }\end{array}$

At the other end of the spectrum are those silencers, which, rather than being impolite, are in themselves gestures of politeness. In (16) Praxagora is reminding her audience of the general principle that it is right to listen to the person who stands up to speak, and unseemly to interrupt him:

(16) Eccl. 588-589

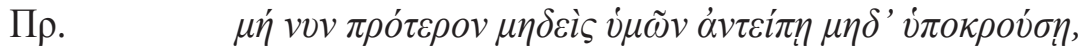

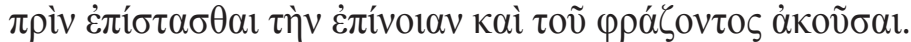

Praxagora Let none contradict nor interrupt me until I have explained my plan and you have heard what I am saying.

Shortly afterwards, Praxagora is annoyed by Blepyrus's asking for an explanation that she was just about to give:

(17) Eccl. 596-598

Пр.

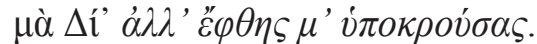

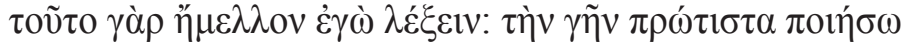

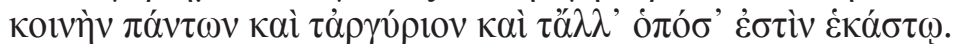

Praxagora No, no, but you interrupted me too soon. This is what I was going to say: I shall begin by making land, money, everything that is private property, common to all.

Finally, in order to have a broader overview of a gender-based use of silencers and fully understand the exceptionality of this instance, we need to mention a long dialogue between Lysistrata and the magistrate (Lys. 507-535). Lysistrata tells him that whereas women used to have to accept in silence the foolish political decisions of men regardless of their possible consequences for themselves, women have now seized power and will take charge of war, while men will sit in silence listening to them. Lysistrata's account of the wives' earlier attempts to talk sense to their husbands falls into two parts; first the wives politely question their husbands, but do not press the issue (Lys. 507-515), then they become so stridently critical that their husbands threaten to give them a sound beating (Lys. 516-520). She specifies the length of time it has taken for the wives finally to lose patience, and gives the impression that they had no choice but to seize power. In the end she threatens to dress the magistrate up like a housewife: wearing a veil and sitting with his woolworking equipment, he will have to listen in silence just as the wives used to do. Here the gender roles are presented as an antithesis between spinning and fighting, and the cross-dressing symbolises the role-reversal that is central to the plot of the play.

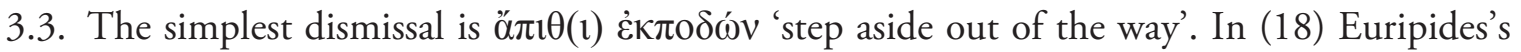
In-law is entering the sanctuary of Demeter disguised as a woman and "she" dismisses "her" slave

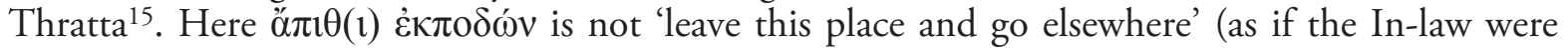

15 Men were strictly excluded from the Thesmophoria and the details of the ceremonies were treated as a great and terrible secret (slaves were not permitted to hear the speeches either). The In-law's female costume is a means to infiltrate the women's assembly. 
sending the slave home), but 'step aside out of the way'. We thus imagine that Thratta is still in the vicinity, albeit barred from participating in the official proceedings:

(18) Thesm. 293-294

$\mathrm{Kh}$.

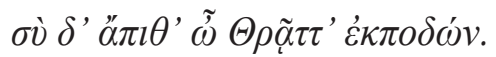

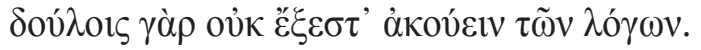

Mnesilochus Be off, Thratta, be off; slaves have no right to be present at this gathering.

In (19) we find a traditional topos of Aristophanic comedy, i.e. women's insatiable love of wine. A woman, who wants to drink wine before giving her speech, is brutally dismissed by Praxagora:

(19) Eccl. 132-137

Пр. $\quad \lambda \dot{\varepsilon} \gamma o 1 \varsigma \alpha \ddot{\alpha} v$.

Гv. A

Пр.

Гv. A

$\Pi \rho$.

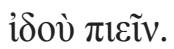

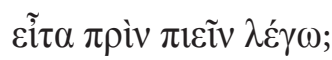

Гv. A

$\Pi \rho$.

Гv. A

Praxagora

First Woman

Praxagora

First Woman

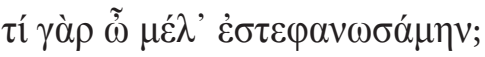

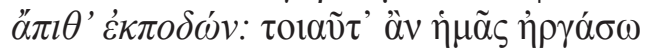

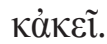

Praxagora

First Woman

Praxagora

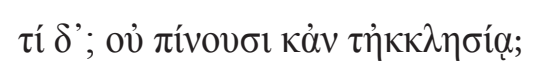

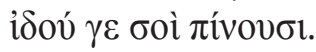

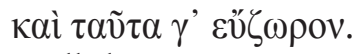

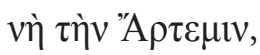

Well then! Begin.

Before drinking?

Hah! She wants to drink!

Why, what else is the meaning of this chaplet?

Get you hence! You would probably have played us this trick also before the people.

First Woman Yes, by Artemis, and strong wine too.

In (20) Cinesias reaches the Propylaia, muttering about his unbearable torment, and is challenged by Lysistrata, who identifies herself as the 'daytime lookout'. She speaks as if the Akropolis were an armed garrison with sentries guarding its boundaries. Interesting for our purposes is the contemptuous repetition of the adverb $\delta \tilde{\eta} \tau \alpha$ 'certainly, of course' in Lysistrata's dismissal:

(20) Lys. 847-849

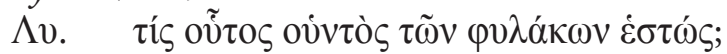

Ki. $\quad \dot{\varepsilon} \gamma \omega \dot{.}$

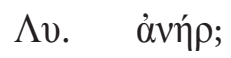

Kl. $\quad \dot{\alpha} v \grave{\rho} \rho \delta \tilde{\eta} \tau^{\prime}$.

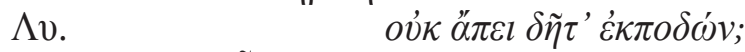

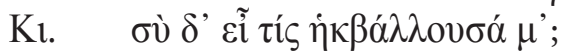

$\Lambda v$.

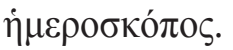

Lysistrata Who is this that stands within our lines?

Cinesias I. 


$\begin{array}{ll}\text { Lysistrata } & \text { A man? } \\ \text { Cinesias } & \text { Too much a man! } \\ \text { Lysistrata } & \text { Then be off at once. } \\ \text { Cinesias } & \text { Who are you that thus eject me? } \\ \text { Lysistrata } & \text { Guard for the day. }\end{array}$

The contrast between Cinesias and Lysistrata is a source of humour, but at the same time it makes the audience realise what would happen if women really did seize power.

The dismissal formula may also consist of an invitation to go and sit down. Disguising themselves as men, Praxagora and her companions arrive at the Pnyx well before sunrise on the day of an Assembly meeting, hoping to secure the passage of Praxagora's motion for control of the state to be handed over to the women. While they are rehearsing this performance, for different reasons Praxagora orders two of her companions to sit down and not to speak in the assembly. In (21) the invitation is even followed by an insult 'You are nothing!', i.e. 'You are worth nothing!'. The woman was complaining about being thirsty, because she had been expecting a drink that she did not receive:

(21) Eccl. 144-146

Пр.

Гv. A

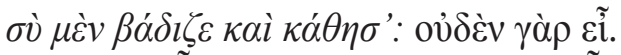

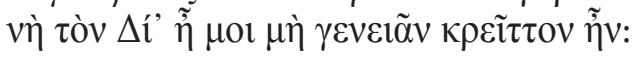

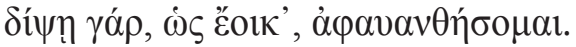

Praxagora Go back to your seat, you are wandering.

First Woman $\quad(<$ Returning to her seat $>)$ Ah! I should have done better not to have muffled myself in this beard; my throat's afire and I feel I shall die of thirst.

In (22) Praxagora is again clearly aware of the importance of using appropriately masculine phraseology and grammar. Although her companion tries to justify herself by blaming Epigonus, a man who looks like a woman, i.e. who do not have a beard, she is dismissed by Praxagora. Initially Praxagora had been uncertain about whether she would speak at the rehearsal, but the complete failure of her companions has made her decide to do so:

(22) Eccl. $166-170$

$\Pi \rho$.

Гv. B

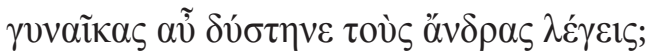

$\Pi \rho$.

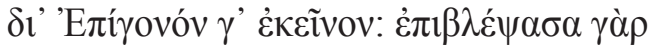

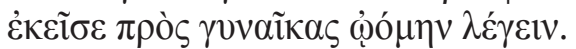

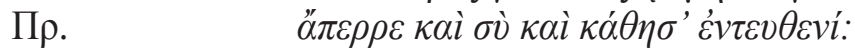

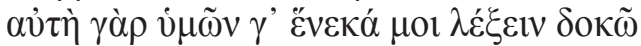

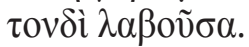

Praxagora Women again; why, you wretched creature, it's men that you are addressing.

Second Woman That's the fault of Epigonus; I caught sight of him way over there, and I thought I was speaking to women.

Praxagora Come, withdraw and remain seated in the future. I am going to take this chaplet myself and speak in your name.

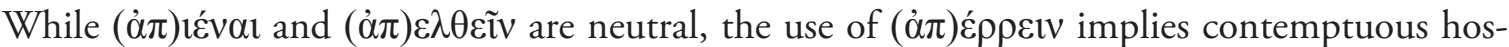
tility. In $N u b$. 783, 'That's drivel. ő $\pi \varepsilon \rho \rho \varepsilon$. I can't go on teaching you', conveys despairing impa-

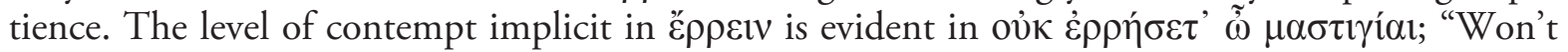
you move on, you sorry loafers there!" (Lys. 1240) that is addressed to slaves who are in the way. 
3.4. Our results can be tentatively summarised as follows. Generally speaking, expressions regarding silencers or dismissals may imply some kind of authority or hierarchical superiority over the addressee. Very often they are uttered using an imperative. The Greek imperative is frequently used without any 'please' word in many types of interaction, although the simple imperative is not as rude in Greek as it is in English ${ }^{16}$. Moreover, these expressions also convey urgency, which is not a form of politeness.

In getting somebody to do something it is also possible to use various grammatical constructions, such as an aorist infinite $(6,14)$ or an aorist optative $(15)$, although the imperatival formulation is by far the most common choice. The difference in meaning between the present and aorist imperative is a thorny issue; however the traditional view about aspect holds true in most cases. The aorist imperative is appropriate when a request is viewed in a comprehensive manner, while the present imperative focuses on the action as a process (often with a durative nuance, for instance, when the lasting effect is stressed or when the fulfilment implies temporal development). Indeed, the aspectual distinction is meaningful in many passages, and the best explana-

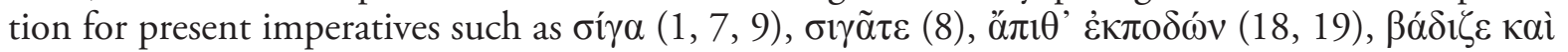

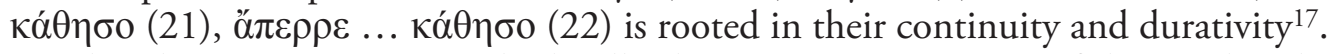

The plain imperative is undoubtedly the most common type of dismissal and silencer in conversations between equals, i.e. $(1-4,6,19,21,22)$. It is also used in commands to someone of a lower rank, i.e. (18). It is possible, however, that other factors may also have been at work. Since the three texts have been selected because they contain a great variety of characters, we will first investigate a possible gender-based use of silencers and dismissals. The results of this classification are presented in Table 1:

\begin{tabular}{l|c|c}
\hline \multirow{2}{*}{$\begin{array}{c}\text { IMPOLITENESS } \\
\text { STRATEGY }\end{array}$} & SPEAKER M & \multicolumn{2}{c}{ SPEAKER F } \\
\cline { 2 - 4 } silencer & ADDRESSEE M ADDRESSEE F & ADDRESSEE M ADDRESSEE F \\
\hline$(1)$ & $\mathrm{x}$ & \\
\hline$(2)$ & $\mathrm{x}$ & \\
\hline$(3)$ & $\mathrm{x}$ & \\
\hline$(4)$ & & \\
\hline$(5)$ & & $\mathrm{x}$ \\
\hline$(6)$ & & $\mathrm{x}$ \\
\hline$(7)$ & & \\
\hline$(8)$ & & \\
\hline$(9)$ & & \\
\hline
\end{tabular}

\footnotetext{
16 For an extensive study of this and related phenomena, see Denizot 2011.

17 For a different view on the opposition between imperative present and imperative aorist, see Amigues (1977), who suggests that the present imperative empha-
}

sizes the execution of the action and signals the effacement of the speaker in front of the agent. Therefore, the play of temporal themes allows the speaker either the strictly necessary expression of the order (imperative aorist), or the "staging" of the action prescribed (imperative present). 


\begin{tabular}{|c|c|c|c|c|}
\hline \multirow{2}{*}{$\begin{array}{c}\text { IMPOLITENESS } \\
\text { STRATEGY }\end{array}$} & \multicolumn{2}{|c|}{ SPEAKER M } & \multicolumn{2}{|c|}{ SPEAKER $\mathrm{F}$} \\
\hline & ADDRESSEE M & ADDRESSEE $\mathrm{F}$ & ADDRESSEE M & ADDRESSEE $\mathrm{F}$ \\
\hline (10) & & & $\mathrm{x}$ & \\
\hline (11) & & & $\mathrm{x}$ & \\
\hline (12) & & $\mathrm{x}$ & & \\
\hline (13) & & $\mathrm{x}$ & & \\
\hline (14) & $\mathrm{x}$ & & & \\
\hline (15) & & $\mathrm{x}$ & & \\
\hline (16) & & & $\mathrm{x}$ & \\
\hline (17) & & & $\mathrm{x}$ & \\
\hline \multicolumn{5}{|l|}{ dismissal } \\
\hline (18) & & & & $\mathrm{x}$ \\
\hline (19) & & & & $\mathrm{x}$ \\
\hline$(20)$ & & & $\mathrm{x}$ & \\
\hline (21) & & & & $\mathrm{x}$ \\
\hline (22) & & & & $\mathrm{x}$ \\
\hline
\end{tabular}

TABLE 1

The distribution of silencers and dismissals in relation to the sex of the speaker and the addressee is shown in Table $2^{18}$ :

\begin{tabular}{lcc}
\hline & M & F \\
\hline speaker & 9 & 11 \\
\hline addressee & 10 & 10 \\
\hline
\end{tabular}

TABLE 2

What then can we conclude about the intersection of gender and silencers or dismissals? Is there any type of difference based on the speaker's gender? Apparently these data do not support the general opinion of gender-based uses of silencers, particularly with regard to their extensive use by men. What is significant is that dismissals are used only by women (or men disguised as women). This is particularly interesting if we consider that Sommerstein $(1995,62)$ has calculated

18 Attestations (5) and (7) were not counted as they are speeches given by the woman herald and by the leader of the chorus rather than dialogues. 
that in Aristophanes' eleven complete plays (a total of c. 15,300 lines) there are about 2,670 women's lines (women's lines comprise those containing something, even a monosyllable, uttered by a female speaker). Of course, female lines are significantly higher in the three selected comedies. Table 3 (from Willi 2003, 174) shows the distribution of women's lines in Lys., Thesm. and Eccl.:

\begin{tabular}{l|cc}
\hline \multirow{2}{*}{\multicolumn{1}{c|}{ Play }} & \multicolumn{2}{|c}{ Women's } \\
\cline { 2 - 3 } & No. & $\%$ \\
\hline Lys. & 768 & 58.1 \\
\hline Thesm. & 708 & 57.7 \\
\hline Eccl. & 636 & 53.8 \\
\hline Other plays & 560 & 4.8 \\
\hline TOTAL & 2,672 & 17.4 \\
\hline
\end{tabular}

TABLE 3

If we consider the total number of female lines in all the plays, the use of silencers and dismissals by female characters in our corpus is clearly noteworthy. However, these data should also be considered in relation to the distribution of the women's lines in the three plays. It is clear that their significance must be considerably reduced and therefore the significance of the data relating to female characters is likewise partly reduced. We have no evidence for a more cooperative and face-respecting female style of conversation. In addition, these features may reflect male stereotypes about women's language and our evidence might thus be filtered through male perceptions.

Before we attempt to draw too many conclusions from this evidence, it is prudent to look at other aspects of the problem ${ }^{19}$. It should be remembered that the characters themselves provide only part of the evidence for classification; the context in which a silencer or a dismissal occurs is also very important. In my data, impoliteness that has the function of entertaining at least some participants (not necessarily the target) and the audience was clearly present. This is the case in (14) and (15), where animal sounds are included. Such expressions, many of them unique, are used for humorous effect in a varied and largely unpredictable fashion. Aristophanes' characters seem to have a virtually unlimited vocabulary, and it is likely that their selection does not reflect the conversational usage of the lowest level of Athenian society, but rather an elaboration and humorous variation of the conversational system of educated citizens. Greek comedy thrives on verbal creativity and conflict, particularly as a means of furthering plot and characterisation. It all creates dramatic entertainment.

19 Modern sociolinguistics has convincingly demonstrated that sex or gender alone is not the only parameter that determines the communicative behaviour of a speaker. Thus, the simple fact that a speaker is female cannot be used to draw far-reaching conclusions. Criteria such as the cultural and social background, level of education, and age of a speaker, as well as the communicative context of an utterance must also be taken into account. Moreover, one should question whether the category of gender can be sufficiently isolated from these other factors. 
A different use is found in (20), where Lysistrata identifies herself as the 'daytime lookout'. She does not use any distinctive expression created for a specific situation, but terms that occur repeatedly in our corpus (in this case in a negative rhetorical question). The irony is determined by the context, and the entertainment factor is also present. Here impoliteness involves entertainment at the expense of its target. The target is not always aware of the impoliteness, but the theatre audience is always aware of who the target is, and even that the target is a 'real' identity. Therefore, we should not focus on a very narrow interactive frame merely involving a dyad comprising a speaker and an addressee. Impoliteness can be designed as much for the audience over-hearing the exchange as for the target addressee. The fact that people can be entertained by symbolic violations of identities and social rights might also be the basis for impoliteness.

In (10), (11) and (12) the sequence of face-threats, mitigation and face-attacks throughout the scene foregrounds the conflict, and serves to add dramatic impetus to the episode. In terms of plot, the conflict generates a state of disequilibrium, which is likely to make the audience wonder how this tension will be resolved by the end of the performance.

The second complex way in which impolite utterances are realised in these data sets is when a particular utterance, or turn at talk, combines two, or even more, different strategies of impoliteness. In (21) and (22) insults follow dismissals; in (12,13) and (15) insults follow silencers. In $(11,13)$ and $(15)$ personalised negative vocatives are used to address the hearer, but never at the beginning of the interaction. This means that they are not used to attract the hearer's attention, but for pragmatic purposes.

4. This paper has presented an approach to linguistic impoliteness in ancient Greek through the analysis of two particular speech acts: silencers and dismissals. The study of (im)politeness is a relatively recent field of historical pragmatics, and Aristophanic evidence has not yet been explored from this angle. Despite the restrictions posed by the data we have at our disposal, examination of verbal duels shows how impoliteness can be constructed discursively in the light of the communicative context and the intentions of the opponent.

To begin with, it is possible to identify some clear examples of silencers and dismissals. It is of prime importance to note that the language of the comedy does have some forms of expression that we might consider specific devices for such communicative intent. However, despite the apparently clear definitions presented by Culpeper 2010a, 3242-3243 (see above 2.1.), it is often challenging to distinguish between dismissals or silencers and other communicative intentions, especially insults, since they sometimes overlap both formally and pragmatically. Written records understood as communicative acts in their own right are always complex and layered. It is thus important for the analyst to take the communicative context into account and to eschew simple generalizations. Put another way, all the forms of expression analysed allow speakers to convey more than one communicative intention.

The results also show that a face-based model directly applying Brown and Levinson's (1987) politeness theory or working from it (e.g. Culpeper 1996; Bousfield \& Locher 2007) can be successfully applied to all twenty-two cases, confirming our initial impression that it is a suitable tool for analysing directive speech acts like silencers and dismissals. Nevertheless, despite its applicability, we also encountered some difficulties. As regards the hypothesis of a gender-based use of these forms, there is no solid evidence in the occurrences selected from the three texts to support the argument that men tend to use more silencers than women (conversely, all the dismissals in our corpus are uttered by female characters). Our data thus suggest that this may not be the main key to interpreting the use of silencers and dismissals in Aristophanes, and that a 
pragmatic — rather than a gender-based use - is at play. This means that the focus should be on the speakers' communicative goals and on the context of interaction. There are two elements that almost always play a part: the relationship of speaker and addressee and the context of the utterance. The relationship between speaker and addressee is made up not only of the identity of the addressee, but also of that of the speaker (age, sex, status, familiarity, kinship, and membership of a group all play a part). In general, linguists have given more importance to the speakeraddressee relationship than to the context (the setting, audience, and topic of discourse) in determining (im)politeness usage. However, analysis of the context allows us to understand that there are times when impoliteness is more strategic, more instrumental, and other times when it is more impulsive. Silencers and dismissals are often used for parodic purposes and not because of their intrinsic value as impolite utterances. The parodic nature of Aristophanes' silencers and dismissals is no serious obstacle to the reconstruction of these impoliteness strategies since parody usually maintains or exaggerates formal characteristics, although it combines them with incongruous content.

In sum, historical impoliteness research would be difficult to imagine without the advances made in research methodology for present-day languages. The more we understand these processes, the better we can understand to what extent material that has already been thoroughly studied can benefit from the application of (im)politeness theories. Conversely, historical impoliteness can add a diachronic dimension to this branch of linguistic pragmatics and thus enrich the debate on the universal and/or conventional bases of (im)politeness.

\section{REFERENCES}

Amigues, S., 1977, «Les temps de l'impératif dans les ordres de l'orateur au greffier», Revue des Études Grecques, 90, 223-238.

Austin, C., \& S. D. Olson, 2004, Aristophanes Thesmophoriazusae edited with Introduction and commentary, Oxford: OUP.

BAX, M., \& D. Z. KádÁR, 2012, Understanding historical (im)politeness, Amsterdam: John Benjamins.

Bousfield, D., 2008, Impoliteness in Interaction, Amsterdam: John Benjamins.

Bousfield, D., \& M. A. Locher (eds.), 2008, Impoliteness in Language. Studies on its Interplay with Power in Theory and Practice, Berlin-New York: Mouton de Gruyter.

Brown, P., \& S. C. Levinson, 1978, Universals in Language Usage: Politeness Phenomena, in: E. N. Goody (ed.), Questions and Politeness: Strategies in Social Interaction, Cambridge: CUP, 56-311.

Brown, P., \& S. C. Levinson, 1987, Politeness. Some universals in language usage, Cambridge: CUP.

Culpeper, J., 1996, «Towards an anatomy of impoliteness», Journal of Pragmatics 25, 349-367.

Culpeper, J., 2005, «Impoliteness and entertainment in the television quiz show: The Weakest Link», Journal of Politeness Research: Language, Behaviour, Culture 1, 35-72.

Culpeper, J., 2010a, «Conventionalised Impoliteness Formulae», Journal of Pragmatics 42, 3232-3245.

Culpeper, J., 2010b, «Researching Impoliteness and Rudeness: Issues and Definitions», in: M. Locher, S. L. Graham (eds.), Interpersonal Pragmatics, Berlin: Mouton de Gruyter, 101-134.

Culpeper, J., 2011, Impoliteness. Using Language to Cause Offence, Cambridge: CUP.

Culpeper, J., M. Haugh \& D. Kádár (eds.), 2017, The Palgrave handbook of linguistic (im)politeness, London: Palgrave Macmillan.

Culpeper, J., \& D. Z. Kádár (eds.), 2010, Historical (im)politeness, Bern: Peter Lang.

Denizot, C., 2011, Donner des orders en grec ancient: étude linguistique des formes de l'injonction, MontSaint-Aignan: Presses des Universités de Rouen et du Havre. 


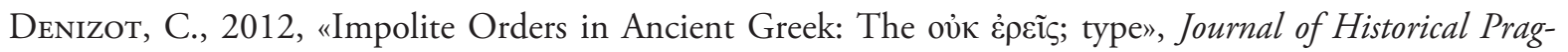
matics $13 / 1,110-128$.

Dickey, E., 1995, "Forms of Address and Conversational Language in Aristophanes and Menander», Mnemosyne 48, 257-271.

DickeY, E., 1996, Greek forms of address. From Herodotus to Lucian, Oxford: OUP.

Eelen, G., 2001, A Critique of Politeness Theories, Manchester: St. Jerome.

Ehlich, K., 1992, "On the historicity of politeness», in: R. Watts, S. Ide, K. Ehlich (eds.), Politeness in language: studies in its history, Berlin-New York: Mouton de Gruyter, 71-107.

Fögen, TH., 2004, "Gender-specific communication in Graeco-Roman Antiquity. With a research bibliography», Historiographia Linguistica 31/1, 199-276.

Fögen, Th., 2010, «Female Speech», in: E. J. Bakker (ed.), A Companion to the Ancient Greek Language, Oxford: Wiley-Blackwell, 311-326.

Holmes, J., 1995, Women, Men and Politeness, London, New York: Longman.

Kienpointner, M., 1997, "Varieties of rudeness: Types and functions of impolite utterances», Functions of Language 4/2, 251-287.

Leech, G.N., 1983, Principles of Pragmatics, London, New York: Longman.

Lloyd, M., 2006, «Sophocles in the light of face-threat Politeness Theory», in: I. J. F. de Jong, A. Rijksbaron (eds.), Sophocles and the Greek language, Leiden-Boston: Brill, 225-239.

López Eire, A., 1996, La lengua coloquial de la comedia aristofánica, Murcia: Universidad de Murcia.

McDonald K., 2016, "The sociolinguistics of gender, social status and masculinity in Aristophanes», Journal of Historical Sociolinguistics 2/2, 155-188.

Mills, S., 2003, Gender and Politeness, Cambridge: CUP.

Poccetti, P., 2014, «Politeness/Courtesy Expressions», in: G. Giannakis et al. (eds.), Encyclopedia of Ancient Greek Language and Linguistics, vol. 3, Leiden, Boston: Brill, 112-114.

Sommerstein, A. H., 1990, Lysistrata, Warminster: Aris \& Philips.

Sommerstein, A. H., 1995, "The language of Athenian women», in: F. De Martino, A. H. Sommerstein (a cura di), Lo spettacolo delle voci, Parte II, Bari: Laterza, 61-85.

Sommerstein, A. H., 1998, Ecclesiazusae, Warminster: Aris \& Philips.

Taillardat, J., 1965, Les images d'Aristophane: études de langue et de style, Paris: Les Belles Lettres.

Unceta Gómez L., 2018, "Gli studi sulla (s)cortesia linguistica in latino. Possibilità di analisi e proposte per il futuro", Studi e Saggi Linguistici 56/2, 9-37.

Watts, R. J., 2003, Politeness, Cambridge: CUP.

Willi, A., 2003, The languages of Aristophanes: Aspects of linguistic variation in Classical Attic Greek, Oxford: OUP.

Wilson, N. G., 2007, Aristophanis Fabulae, Recognovit Brevique Adnotatione Critica Instruxit, Tomus II, Oxford: Oxford Classical Texts. 